\title{
MEDICINE AND THE ROMAN ARMY: A FURTHER RECONSIDERATION
}

\section{VIVIAN NUTTON}

Professor John Scarborough in a recent article in this journal has discussed the relationship between doctors and the Roman army, but his methods and his conclusion, which may seem to some to compel assent, demand a cautious and thorough examination before being accepted. ${ }^{1}$ As Sigerist saw, it is necessary to exclude modern preconceptions and to avoid the obfuscation of an account by the introduction of evidence from different periods and cultural contexts. Roman military medicine extends over many centuries, from Polybius writing in the second century B.C. to Paulus of Aegina and Alexander of Tralles in the sixth century A.D., and the army of the empire differs in organization, composition and purpose from that of the Republic. Thus an investigation of Roman military medicine must take care not to introduce terms and evidence that are chronologically insecure and it must consider the medical services of the army within the context of the army and secondly within that of Roman medicine as a whole. A full and detailed exposition of all the evidence would consume much space, but there are objections to and clarifications of Scarborough's article that can be made briefly and without producing those arguments that require broad discussion or that have implications for more than the study of ancient medicine. This article, therefore, sets out destructive arguments rather than constructive proposals, although some idea may be gained of the direction in which further research is needed or in which $I$ hope to develop some of my suggestions.

I begin with a summary of Scarborough's conclusions, which are complicated and somewhat difficult to follow. The republican evidence attests the presence of private doctors in the army, brought by the general and by those who could afford them, and there was no corps of doctors but only 'a kind of de facto medical service of soldier-medici'. ${ }^{2}$ Under the empire the need for medical care was filled by having the wounded cared for on the field and the sick and severely wounded placed in valetudinaria. $^{3}$ Trained physicians were rare and the sick were treated by medici, soldiers in the ranks specially detailed for the post who gathered their craft within the legion. Military medicine was confined to wound surgery and could be easily learned by such men." There is an 'unofficial basis' admitted in many cases, and, as

1 J. Scarborough, 'Roman medicine and the legions: a reconsideration', Med. Hist., 1968, 12 , 254-61. Other important works which deal with this problem and which will be referred to by the name of their author alone are: A Casarini, La medicina militare nella leggenda e nella storia, Rome, 1929; H. Gummerus, 'Der Ärztestand im römischen Reiche, I', Societas Scientiarum Fennica, Commentationes Humanarum Litterarum, 1932, III.6; A. von Domaszewski, Die Rangordnung des römischen Heeres, 2nd ed. Cologne/Graz, 1967; H. A. Callies, 'Zur Stellung der Medici im römischen Heer', Med.-hist. J., 1968, 4, 18-27.

Abbreviations that will be used are: CIL: Corpus Inscriptionum Latinarum; ILS: H. Dessau, Inscriptiones Latinae Selectae, Berlin, 1954;

RIB: R. G. Collingwood and R. P. Wright, The Roman Inscriptions of Britain, Oxford, 1965; AE: L'année épigraphique.

Scarborough, p. 257.

Ibid., p. 258.

Ibid., p. 259. 


\section{Medicine and the Roman Army: a Further Reconsideration}

time passed, the camp prefect was placed in charge of medical care and the soldiers received less attention. If trained physicians were present among the legions in the later empire, the type of medicine they practised reminds us more of the ill repute of certain doctors of the early empire. ${ }^{5}$ The Roman army medical services are thus informally organized, training men from within the legion in skills that were quickly learned and that had an immediate practical application.

As will be seen, I agree with few of these conclusions, and common ground between our interpretations is small and confined to two basic points. First, there is no evidence for doctors organized in a corps of army doctors and then distributed among the legions and auxiliary troops: instead in the first three centuries A.D. each legion, cohort or ala had among its members medici who presumably attended their fellow soldiers. ${ }^{6}$ Secondly, emperors, and probably legates, brought their own physicians and in an emergency these and other non-military doctors could be employed. ${ }^{7}$ Beyond these two points all is obscure and debatable, and I confine my comments on Scarborough's thesis to three sections: a discussion of certain terms and concepts used by him, criticism of the evidence for the late republican period, and an examination of the epigraphic record of imperial military medicine.

Terms such as 'formal' and 'informal', 'organization' and a 'de facto medical service' are too imprecise or beg the question, and their use obscures many of the merits of an interesting article. To say that there are few medici or insufficient or that their services are inadequate relates neither to formality nor to organization, and, as much of this thesis is concerned with these words, they demand close scrutiny. ${ }^{8}$ Blau and Scott have attempted to define a formal organization in sociological terms, and, although it is conceded that their use here is anachronistic, the attempt must be made to clarify the concepts used in the discussion. A formal organization is contrasted first with a social organization that arises wherever men live together, and it is decided that it differs because it is established for a certain purpose, having certain goals, rules and ideologies. It differs too from the informal organization because its members, goals and status structure have not spontaneously emerged in the course of social interaction. Even an informal organization must exist within the formal organization which constitutes its immediate environment. ${ }^{9}$ This distinction which is admitted to be solely analytical does not take us very far; it is sufficient, however, to stress the purpose and the lack of spontaneity that characterize the formal organization, and to admit that this sociological definition must be supplemented in order to obtain a meaningful analysis of the Roman army. I suggest that as a further criterion for 'formal organization' we add legal recognition of a group and of its members, and some discernable hierarchy of rank and title. One may consider the further possibility that training within the ranks of the legion, if explicitly mentioned in a formal context, implies an organization by which this is to be done.

Ibid., p. 260.

- This is the opinion of Domaszewski, pp. 45, 55, 58, and of Callies, p. 23.

'Emperors; Velleius, II, 114.2; Dio Cassius, 77.3.4. ${ }^{2}$ : legates, see A. H. M. Jones, Studies in Roman Government and Law, Oxford 1960, pp. 154, 202 n.5. On other doctors used in emergency, Tacitus, Annals, I, 69.

8 Scarborough, pp. 259-60. For the difficulties of having too many doctors see the words of Hadrian reported by Dio, 69.22.4.

- P. M. Blau and W. R. Scott, Formal Organizations, London, 1963, pp. 5-7. 


\section{Vivian Nutton}

Proof that the Roman army medical services were formally organized is hard to find, although it is not difficult to assume that if the army is regarded as a formal organization, the duties of a constituent group are equally formally organized. But this is not enough to counter determined scepticism, and evidence must be marshalled in support.

There is agreement that the doctor was a member of the army: by taking the military oath he became a soldier, a miles-and it should be remembered that until he reached the rank of centurion he was still technically a miles, albeit miles principalis or miles immunis - his service was counted in stipendia, and he was bound by military law. ${ }^{10}$ This does not mean that his duties necessarily included fighting, and Aelian and Arrian, who follows him or his source, expressly include the doctor among the non-combatants along with the supply officers and those who serve in the legion and minister to a particular need.11 We are thus not dealing with a quasi-autonomous medical corps but with members of the army, and legal recognition takes place within the army. The second-century lawyer Tarruntenus Paternus states that the medici and other specialists ranked with the 'immunes', those who received freedom from certain routine duties in return for the performance of certain services. ${ }^{12}$ These included the certification of those unfit or requiring a discharge, and for this they received immunity that was legally valid, and protection of property acquired before entering the army against those who desired to sequestrate it. ${ }^{13}$ This is a clear statement of the legal recognition of the medicus within the army, and of some of their duties and reciprocal privileges, and I conclude that this implies a formal organization of the medici comparable with that of the administrative staff of the legion or with other specialists.

But legal recognition of the doctor within the army is only one aspect and does not lead inevitably to the discovery of an organization, and it may be argued that the acceptance in law of medici refers to individuals and not to any group. Yet proof of something more than chance or haphazard medical services comes from a study of the archaeological evidence provided by legionary hospitals. Scarborough asserts that the Romans made a division between sick and wounded and that the valetudinaria and the widely-used sanitary measures abolished the devastations of disease among the military fortresses. ${ }^{14}$ No military hospital survives from the republican period and this argument is valid only for the empire, although its conclusion may be projected back. The valetudinarium shows a standard plan and position: with the excepttion of Haltern, which resembles a group of tents in wooden form and which is the earliest surviving legionary hospital, the valetudinaria are based upon a similar plan throughout the empire. With the hospital at Inchtuthil in Perthshire can be compared those of Novaesium or of Bonn, and even auxiliary forts show similar plans for their

10 On the military oath, see C. E. Brand, Roman Military Law, Austin, 1968, pp. 91-98; on stipendia, CIL III 14349.7, Gummerus n.396, and $A E, 1903,290,376$; cf. also the references collected by P. Cauer, 'De muneribus militaribus centurionatu inferioribus', Ephemeris Epigraphica, 1881, 4, 358-481, esp. $432 \mathrm{ff}$.

11 Aelian (and Arrian), Tactics, ed. Köchly, 248. On the administrative staff, see Cauer, op.cit., 412-20, and Jones op. cit., 161-65.

12 Digest, 50.6.7.

13 Codex Justinianus, 12.35.6.; Digest, 4.6.33.

it Scarborough, pp. 257-59. 


\section{Medicine and the Roman Army: a Further Reconsideration}

hospitals. ${ }^{15}$ In a military advance base such as that at Hod Hill traces of a hospital have been found which served the needs of both legionaries and auxiliaries. ${ }^{16}$ At Inchtuthil the hospital is the largest completed building on the site and shows such refinement of design and such attention to detail that its planning, construction and use cannot have been left to chance. I therefore conclude that this standardized plan and the refinements which may be seen to have developed in its design, prove the existence of a standard organization of the personnel within the hospital which cannot be ascribed to the vagaries of chance and informality. As with all the camp buildings the hospital was under the control of the camp prefect and it was administratively managed by an optio valetudinarii. ${ }^{17}$ The medicus castrorum or castrensis will thus be the medical officer in charge of the medical services of the fort and command the capsarii, or medical orderlies, and the medici. ${ }^{18}$ This hierarchy, which is conjectured from the evidence of inscriptions, may derive some support from obscure literary references, and I suggest that the presence of the status structure and the existence of standard buildings and plans argues for a 'formal organization'.

Even if it can be accepted that the Roman army made a distinction between sick and wounded, it is relevant to ask who attended to them. Are we to assume that capsarii dealt with minor wounds-and they could obviously be used in emergencies as medici ${ }^{19}$ - while the medici treated the sick, for diseases occurred even after the introduction of hospitals and sanitary facilities? ${ }^{20}$ In legionary fortresses such as Caerleon where the legion was some way behind the frontier and only took part in occasional fighting, the greater number of patients must have suffered from illness, not from military injuries. ${ }^{21}$ This division, even if too schematic, at least is plausible, and exhortations to physical exercise and right living by generals and military theorists, far from disparaging the abilities of physicians, reflect the general's justifiable concern to prevent illness, morale failure and dissension. ${ }^{22}$ An army that remains healthy by exercise and training is obviously of greater use than one in which doctors, however

${ }^{15}$ Contrary to Scarborough's statement in n.33, the evidence for legionary hospitals is small. The only general survey of a particular area is that of $\mathbf{R}$. Schultze, 'Die römische Legionslazarette in Vetera und anderen Legionslagern', Bonner Jahrbücher, 1934, 139, 54-63. On Haltern, see Schultze, p. 59, and pl.IV n.1; on Inchtuthil, Journal of Roman Studies, 1957, 47, 198 and figs. 8 and 9; Novaesium, Schultze, pp. 59-61 and pl. IV n.3; Bonn, H. Petrikovits, Das römische Rheinland, Cologne, 1960, pp. 42-43, and pl. 3. On auxiliary forts and their hospitals, cf. I. A. Richmond, 'The Roman Army medical services', Durham med. Gaz., June 1952, 2-6, p. 5 . Note also Hyginus, III.34.

${ }_{16}$ I. A. Richmond, Hod Hill, London, 1968, p. 86 and fig. 47.

${ }_{17}$ Vegetius, II.10. CIL III 14537 may refer to the prefect of the cohort, not of the camp. Scarborough's references, p. 261, are irrelevant; CIL III 3413 depicts a curagens and the Vita Aureliani VIII. 8, refers to the vicarius of the emperor. On the optio, ILS 2117, 2437, $2438+A E 1906,9$.

${ }_{18}$ Castrensis, ILS 2126, AE 1937.180; castrorum, ILS 2193a with which compare Achilles Tatius, IV. 10 and Cramer, Anecdota IV.404; capsarii, ILS 2438, 2437, 9182, Digest 50.6.7.

io Dr. J. K. S. St. Joseph who is publishing the report on the legionary fortress of Inchtuthil tells me that he and Richmond calculated that at least one medical attendant was required for each century, as each century had its own ward within the hospital. If this requirement was not metand one may assume that after a battle it may not have been-then outside assistance or attention by the troops themselves could remedy the ensuing chaos, cf. Tacitus, Annals I.69, Histories, II.45. In contrast to the expected casualty rate of 2.5 per cent, or a maximum of 10 per cent, at Inchtuthil, a base fortress, Richmond calculated, Hod Hill, 86, that a minimum casualty rate of 12.5 per cent was expected at this advance fort.

80 Scarborough's suggestion, p. 257, that no disease devastated the army after the introduction of sanitary measures and hospitals is not confirmed by the stories of plagues, on which see J. F. Gilliam,

'The plague under Marcus Aurelius', Amer. J. Philol. 1961, 82, 225-51 (248 ff.).

${ }_{21}$ Caerleon, Journal of Roman Studies, 1965, 55, 199.

22 Vegetius, III.2 cf. Onasander, I.12. 


\section{Vivian Nutton}

excellent, treated patients who were sick. Even Galen recommended exercise as a prophylactic and the emperor Hadrian discoursed upon the idiosyncrasies of military exercise and training. ${ }^{23}$ To argue from the doubtful evidence of reliefs and from the details of military medicine embedded in larger works, which emphasize the peculiarities of medicine in the army, is to mistake the part for the whole, and to neglect probability, the evidence of fortresses, and the statements of Galen. ${ }^{24}$

The second part of Scarborough's argument against a 'formal organization' assumes the absence of official training and of physicians trained in the manner of Galen, and stresses the apparent informality of entry into the ranks of the Roman army medical services. ${ }^{25}$ It is agreed that the method of entry appears to the modern viewer informal and unusual, but in the cultural context of ancient medical education this is only what is to be expected. There were few medical schools and even these may have been accretions of pupils around a particular master who represented a medical tradition such as that of Asclepiades or of Erasistratus. ${ }^{26}$ Success and experience were the main, and in most cases the only, qualifications. A cobbler turned to medicine and Thessalus who claimed to be able to teach medicine within six months did not lack pupils and supporters. ${ }^{27}$ Even those who were trained within a family or by a master began their training at an early age and could be regarded as qualified by the time they reached the age of twenty. ${ }^{28}$ Galen who is often seen as the model to which all other ancient doctors are to be compared expressly dissociates himself from others and insists upon his long, detailed and unusual education. ${ }^{29}$ Thus there is a possibility that men who enlisted in the army at the age of twenty could be considered as trained doctors, especially as experience and success were the major qualifications. The picture of medical education generally is one of informality and improvisation, and thus this particular aspect of military medicine, which forms part of the general informality, cannot be used to prove the informality of all medical services in the Roman army.

Yet for those who conjecture formal instruction within the army, supporting evidence is not lacking. Scarborough supposes that some teaching was carried on by the senior medici, and it must be admitted that this could be called informal even though a consideration of the organization and structure of the Roman army would appear to render this unlikely..$^{30}$ But clearer proof is to hand: a fragmentary inscription from the legionary fortress of Lambaesis in Algeria records a collegium that includes an optio valetudinarii, the pequarii or veterinary surgeons, a librarius or clerk, and the

${ }^{23}$ Galen, Scripta Minora, ed. I. Marquardt, I, 93-102; ILS 2487.

24 Galen, V. 160, XIV 244; Rufus of Ephesus, 212; the relief on Trajan's column depicting a wounded man being treated, K. Lehmann-Hartleben, Die Traianssäule, Berlin, 1926, P1. 22, was assumed by Richmond, Durham med. Gaz., 1952, 2 to refer to capsarii, and the Burnum relief, $H$. Liebl, 'Zum Sanitătswesen im römischen Heere', Wiener Studien, 1902, 24, 381-85, which does not describe the dead man as a doctor, has been assigned by Callies, 19 n.6., to a 'Krankenwärter'.

${ }^{25}$ Scarborough, p. 260.

26 On schools at Marseilles, Tarsus, Pergamum and Alexandria, see Galen, VIII 726-7, XI 114, XII 776, XIX 52, 58, 59; on Ephesus, J. Keil, Jahreshefte der Ósterreichischen archäologischen Institut, 1905, 8 B. 128-38; at Rome, A. Pazzini, 'La schola medicorum ad Aesquilinas', Atti del terzo congresso di studi Romani, 1, Rome, 1935, 467-72. For other possibilities in the West, see ILS 6507, 7786, CIL V.6970.

${ }^{27}$ Phaedrus I.14, Galen IX 804. The tradition on Thessalus is uniformly hostile.

28 (Soranus), Introductio, 244; CIL XII 533.

29 Galen, X. 561, XIX 59.

${ }^{30}$ Scarborough, 259. 


\section{Medicine and the Roman Army: a Further Reconsideration}

discentes capsariorum. ${ }^{31}$ Who are these discentes capsariorum? Whether they are the pupils of the hospital orderlies or better still, taking the genitive as partitive, the pupil hospital orderlies, it is clear that they are being taught, and formally taught, for the inscription which records the constitution of this association shows that they are recognized as undergoing instruction. Nor is this the relationship of one master to one pupil, for the plural suggests something more than mere improvised instruction. No certain parallel for instruction in similar specialities within the Roman army can be found, although some have discovered a trainee architect serving in a German legion and a trainee surveyor in Rome, and trainee cavalry and standard-bearers are known. ${ }^{32}$ I venture to suggest that if some instruction was provided for the capsarii, who may be assumed without difficulty to have entered the army untrained, then there was some medical instruction available for those drafted as medici. Speculation suggests that capsarii by experience could become medici, and the conjunction of a medicus ordinarius and capsarii on an inscription from Niederbierber in Lower Germany may indicate that these hospital orderlies were under the care and instruction of such a senior medicus. ${ }^{33}$

But it may be that trained doctors did enter the army: Scarborough vacillates on this point, possibly rightly. ${ }^{34}$ First, comparative evidence from other specialist groups within the Roman army can be brought: an architect already trained joining the legion at Aquincum at the age of thirty, and the importation of specialists from civilian life may be assumed to have satisfied such needs of technically proficient man-power. ${ }^{35}$ But more certain evidence attends. As most doctors in the first two centuries A.D. who are known to us from literary and epigraphic evidence are of Eastern origin, and as the profession of medicine in the East carried status and respect, it is likely that many recruits who became doctors were Greeks entering either after some medical experience in civilian life or as recruits, either because of the status attraction of the profession, or because, as most textbooks were written in Greek, Greeks were the obvious choice to be singled out and thus assigned to the medical services. ${ }^{36}$ The exact demarcation of the extant Greek doctors into those who entered as untrained recruits and those who were drafted as trained Hellenistic physicians is very uncertain. Pedanius Dioscorides was certainly a trained doctor when he enlisted, as were Scribonius Largus and, if Sander's suppositions are correct, Archigenes of Apamea; the literary doctor, Callimorphus, may also be presumed to have had some previous medical training. ${ }^{37}$ To deny the existence within the legion of men who had

${ }^{31}$ ILS $2438+A E$ 1906, 9; Domaszewski, 45.

32 CIL XIII 7945, but cf. the reading of ILS 2459; CIL VI 32536, 3409; Domaszewski, 45.

s3 ILS 9182, Gummerus 373.

s4 Compare Scarborough, 260 line 18 with 261 line 8.

ss Die römische Limes in Österreich, 1926, 16, 36-37, n.31, AE, 1954, 119.

${ }^{86}$ I have here stated dogmatically my opinion on several disputable subjects, all of which require long and detailed discussion. On the Greek attitude towards doctors, see the material collected by $\mathbf{S}$. Reinach, in C. Daremberg and E. Saglio, Dictionnaire des Antiquités, s.v. medicus, III 1669-1700; the problem of the availability of textbooks is complicated by the fact that only Celsus, Largus and Pliny survive of the Latin authors on medicine who lived in the first three centuries of the Christian era, and their works and those of their Latin contemporaries, are eclipsed by the Greeks such as Dioscorides, Galen and Rufus.

${ }_{37}$ Dioscorides I.4; Largus, 162, cf. F. E. Kind, Berlin. Philolog. Woch., 1913, 33, 1334-39; Cramer, Anecdota IV 404, with E. Sander, 'Zur Rangordnung des römischen Heeres; der duplicarius', Historia $1958,9,239-43$ (241), but the identification is not convincing; Lucian, Quomodo Historia, 16. That doctors might be expected to own property before enlisting is clear from Digest 4.6.33. 


\section{Vivian Nutton}

received instruction in medicine in civil life is a failure to observe all the relevant evidence, and even if it is impossible to decide whether a Greek doctor recorded upon an inscription entered before or after training the former possibility cannot be ruled out. The provisions for medical education and for the drafting of suitable recruits are thus surer than Scarborough admits, and even if it is allowed that the system of medical education was informal, the fact that this is true of almost the whole of antiquity means that this argument for the informality of military medicine cannot be pressed. An army doctor after his experience and service could be considered as fully qualified, and the law codes advocate and inscriptions confirm the entry of a military doctor upon retirement into the select group of civilian doctors who possess immunity from certain taxes and civic duties. ${ }^{38}$ If medical education and practice within the legion were confined to elementary wound surgery and brief rules about sanitation we should not expect this interchange between military and civilian posts, and its existence refutes those who rely upon the apparent peculiarity of military medicine to prove informality.

Thus far certain concepts have been examined and rejected: the Roman army in the Empire made provision for medical attention, gave legal approval to its medical staff and endeavoured either to secure trained physicians or to train men from the ranks. Even if we must reject Scarborough's main thesis, it is still necessary to examine his use of evidence, first for the republican army, and secondly for the empire.

The War Commentaries of Julius Caesar are the starting-point for any discussion of the republican army, and it thus appears strange to find in them no mention of medici and no details of the treatment of the wounded. Yet not so much is thereby proved as Scarborough thinks: there is no provision made for the hospitalization of the troops, but this need not bear upon the existence of medici. Even after treatment on the field the seriously wounded needed time and rest in order to recover, and in the absence of hospitals, which is what the literary evidence suggests, it was best to billet them upon friendly towns and tribes. ${ }^{39}$ But who treated the wounded on the battlefield? Scarborough assumes the existence of men with some medical knowledge, medici, but from the scantiness of the available evidence it is impossible to say whether they were given a specific position within the republican army. ${ }^{40}$ The evidence of Cicero surely indicates that there were medici who attended the wounded and whose aid was expected and sought by those in need. 'The customary use of the medicus (to dress wounds) is well established and the medici are looked to by their fellow

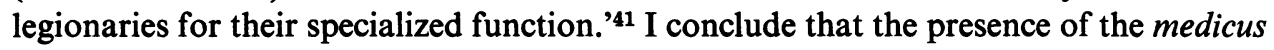

${ }^{38}$ Codex Justinianus 10.53 .1 ; ILS 2542, a doctor who served with an auxiliary cavalry unit in Germany later was granted a salary by the civitas Feretensium.

${ }^{30}$ Scarborough, p. 257. A word of caution is required; the earliest known hospital, that of Haltern, shows a plan that obviously derives from a collection of tents, tentoria, and it may be that these served as the places in which soldiers were kept and treated by the official medici, Schultze, op. cit., p. 59 and P1.IV n.1. Descriptions of individual heroics do not necessarily prove that Caesar had a 'regard for the safety and well-being of his legionaries' and although we may agree that Caesar was 'a great leader of men', it is difficult to see the connection between this and the existence of a medical service.

40 See the references given by Scarborough p. 257, n. 19, 20.

4 Cicero, Tusculan Disputations, II.16.38; at vero ille exercitatus et vetus ob eamque rem fortior medicus modo requierens a quo obligetur. 'The old hand simply looks for a medicus to bandage him'. I fail to see how Cicero can be accused by Scarborough, p. 256, of 'imprecise' Latin and why the 'modern reader should be left with the impression that the medicus was just another soldier, but one who had been judged experienced among the legionaries in problems of wound dressing' is 


\section{Medicine and the Roman Army: a Further Reconsideration}

and his general acceptance may indicate more than a mere 'de facto' medical service, although I do not go so far as to see a corps of doctors, and it is possible to see provision for doctors other than the personal physicians of the wealthy and a 'formal' recognition of the position of the medicus.

The republican evidence is too scattered and fragmentary to be relied upon to furnish a definite conclusion, and an argument 'ex silentio' does not carry much weight. Thus Scarborough may be correct in his interpretation of the evidence for the late republican army, yet his attempt to apply these tentative conclusions to the fuller and more exact evidence of the imperial army breaks down upon his ignorance of the epigraphic material. To support a dubious thesis, the evidence of inscriptions is set out incorrectly and tendentiously translated, and where exact numbers are required, vaguely numerical adjectives are employed to create the desired impression. I calculate that there are ninety-seven inscriptions that relate to the Roman army medical services and six papyri, some very doubtful indeed, and these numbers must be borne in mind when considering some of Scarborough's statements about the frequency of particular titles. 'The informality of title is firmly indicated by the multiplicity of designations of the medici in the legion' and 'in the Latin inscriptions other titles abound. ${ }^{\mathbf{4 2}}$ It is possible and necessary to divide up the varying epithets into the following groups: medicus legionis/cohortis/alae: medicus castrorum/castrensis: miles medicus: medicus ordinarius: and medicus together with an adjective referring to a particular speciality, medicus clinicus/veterinarius/chirurgus. The first group can be omitted from consideration for they indicate the unit in which the doctor serves, and also the last group, for on private tombstones the addition of such specialities may be either an idiosyncrasy or a reference to a particular specialization within the army.43 Thus it is clear that the titles that are in dispute are three, medicus castrorum/ castrensis: medicus ordinarius and miles medicus. The camp doctor is mentioned only three times on inscriptions, and twice by Greek authors, and I have assumed that he was in charge of the medical services within the castra. ${ }^{44}$ Miles medicus is also rare with only two examples: it should be noted that the order of the words is not reversed and the analogy of miles pecuarius, miles a curis, and miles librarius suggests that the man was a medicus who served in the army..$^{45}$ As I have already stated, the doctor upon taking the military oath automatically became a soldier, miles, although this did not mean that he was a combatant, and he would retain that rank until his

beyond understanding. Only the most tendentious would see in this a reference to any other than a doctor or a person skilled in medicine, and seek to confuse the issue by introducing Apollo medicus and the poets. Note that at $256 \mathrm{n} .13$, all the prose writers cited assume that the medicus is 'what we would term a physician or a surgeon'. Bishop Atterbury assumed that Vergil was describing, not a soldier-doctor, but the famous Antonius Musa; F. Atterbury, Antonius Musa's character as represented by Virgil in the person of Iapis; a dissertation, London, 1742.

12 Scarborough, p. 258 n.27.

43 Callies, pp. 19, 23; it is worth remembering that on the formal inscriptions set up by the cohorts of the Watch to honour Caracalla in 210 A.D., CIL VI 1058, 1059, and on the great inscription set up by a vexillation of Legio XI Claudia near Sofia, CIL III 7449, the doctors are called medicus only. Cf. also Mommsen's comments on the last inscription, Gesammelte Schriften, VIII, Berlin, 1965, p. 407.

${ }_{44}$ Above n. 18. As Scarborough rightly notes, the medicus duplicarius is confined to the fleet; of his examples, CIL VII $1144\left(R I B 2315^{*}\right)=X 3441$.

${ }_{45}$ CIL III 14347.5 from Aquincum; XIII 7943 (dated to 161) from Iversheim; another example, III 4061 (Gummerus $98 \mathrm{n}$. 385), is refuted correctly by Dessau, ILS 2330. Miles pecuarius, ILS 2431; a curis, 2412; librarius 2424. 


\section{Vivian Nutton}

promotion to the rank of centurion. Thus miles medicus, which appears only on private inscriptions, can be explained as the designation of a doctor within the army, possibly even as a doctor who has been trained within it after entering as soldier in the ranks.

Finally and most difficult is the designation, medicus ordinarius, which occurs five times only, on inscriptions which cannot be earlier than A.D. 150 and may date from A.D. 200 at the earliest. ${ }^{46}$ Scarborough's explanation is that 'since Caesar's council was one of men taken from the ranks and distinctly one of an informal nature, the medicus ordinarius, medicus cohortis and medicus legionis functioned on the same basis.' ${ }^{\prime 27}$ Even were these statements about Caesar's council true, caution, if not disbelief, would be demanded when we are asked to explain the origin of a title by the evidence of an institution that existed at least two hundred years earlier, a republican army council. But Caesar's council is neither informal nor one of men taken from the ranks: neither a centurion nor a military tribune can be called a ranker, the former occupying superior positions to the milites, the latter being equestrian officers, and the members of the council appear to be agreed. ${ }^{48}$ The tribunes and centurions of the leading orders are the most experienced officers of the legion, and their presence, and the absence of any soldiers, surely defeats Scarborough's attempt to prove that ordinarius must indicate a soldier in the ranks.

A full discussion of this title, which cannot mean that 'the individual was a soldier in his duties, not a physician', would require the citation of all the references to ordinarii, and ordinati and an examination of all the specialists in the Roman army, and it is better to state the varying opinions that have been held, and to indicate my own preference.

Domaszewski and J. F. Gilliam believed that the medicus ordinarius was a doctor serving in the army as distinct from a civilian doctor, and preferred to rely upon the apparently definite statements of Vegetius and Festus. ${ }^{49}$ Mommsen modified this view and stated that this was a doctor in the legion who received a stipendium as opposed to a salarium as a senior member of the army, and Cheeseman and Passerini developed this to mean that the medicus ordinarius was a lower-grade doctor within the legion than the medicus. ${ }^{50}$ Sander, however, thought that the medicus ordinarius held centurion rank and commanded other doctors or capsarii, although many of his arguments and the general thesis of the article in which he expressed his view have not found general acceptance. ${ }^{51}$ This last view seems to me to be probable and would explain the rich decoration on the tomb of Anicius Ingenuus and the dedication to the genius of the capsarii made by a medicus ordinarius. ${ }^{\mathbf{5 2}}$ Scarborough's arguments do not advance the debate and when only five instances of this title are known, it may be best to conclude that, although the doctor served in the army, his rank and

${ }^{46}$ ILS 2432, 9182; CIL III 4279, 5959; RIB 1618; the conjectural restorations of medici ordinarii at Castra Regina CIL III 6532, and at Lanuvium XIV 4178, cannot be used as evidence as the epithet is applied to other members of the army.

17 Scarborough, p. 258.

is On this see especially J. Suolahti, The Junior Officers of the Roman Army in the Republican Period, Helsinki 1955, pp. 35-51.

"Domaszewski, p. 45; J. F. Gilliam, 'The ordinarii and ordinati of the Roman Army', Trans. Amer. Philol. Ass., 1940, 71, $127-48$.

${ }_{50}$ Mommsen, op. cit., p. 376 n. 2; G. L. Cheeseman, The Auxilia of the Imperial Roman Army, Oxford, 1914, p. 44; A Passerini in De Ruggiero's Dizionario Epigrafico, IV, p. 608, s.v. legio.

${ }^{51}$ Sander, op. cit., pp. $240-41$.

s2 RIB 1618, Callies, p. 24; ILS 9182. 


\section{Medicine and the Roman Army: a Further Reconsideration}

hierarchic position must be left in doubt for the moment. The statements made by Scarborough in his section on inscriptions do not inspire the reader with confidence in his conclusions. The tombstone of Anicius Ingenuus, which is decorated with shields and the relief of a hare, bears the following inscription: 'To the shades of Anicius Ingenuus, medicus ordinarius of the first cohort of Tungri; he lived twenty five years. ${ }^{53}$ The 'terse terms' of the gratitude of his cohort and his great respect among his fellow auxiliaries are hard to find, and it is unwise to assume that this tomb was erected by the cohort as a mark of thanksgiving to their doctor for his compassion. Even more misleading is the statement that the epitaph to Claudius Hymnus was composed in similar fashion. This reads: 'To Claudius Hymnus, doctor of the twenty first Claudian legion, and to Quieta Attica, his wife. Atticus their (his, her?) patron set this up. ${ }^{54}$ There is no indication that this was erected by his fellow soldiers, and although there is dispute and uncertainty about his civil status and even his position within the legion, any suggestion of compassion or of a thankful commemoration of a deserving and kindly doctor is wishful thinking. The designation of the doctor in CIL VI 2532, a man of considerable wealth, is medicus clinicus cohortis IIII praetoriae, and how the modern reader is to observe from the tone of this inscription-or from any other mentioned in this section-'the use of scientific magic in the taking of vows in connection with the function of the medicus in the legion' is incomprehensible. ${ }^{55}$ None of the inscriptions discussed is a dedication or informs us of vows for the safety of either patients or doctors, and to introduce scientific magic is to complicate an already obscure subject. There are indeed dedications to Asclepius and other healing deities within the legionary fortress, and Egger has recently concluded that this signifies that official approval has been given to those cults whose dedications are found close to or in the praetorium. ${ }^{56}$ We are also informed by Scarborough that Greek inscriptions show another side of the story, and we yearn to know what side. True, a Greek physician is found at Egyptian Thebes with legio II Trajana, but it has long been noted that the names of many, if not most, doctors in the army, whether legionaries or auxiliaries, suggest an Eastern origin for their owners. ${ }^{57}$ We are further invited to believe that an Egyptian temple physician services XXII Deiotariana in the Hellenistic tradition. ${ }^{58}$ Even were we certain of the meaning of this tradition, this statement would be fantasy. The most that can be concluded is that Aufidius Clemens, doctor in XXII Deiotariana, who made a vow to Lord Hermes at the shrine of Pselci some time before the death of Hadrian, was a worshipper of that God, and there is nothing

ss Scarborough, p. 258; RIB 1618. This was comprehensively discussed by J. Y. Simpson, Archeological Essays (ed. J. Stuart), Edinburgh, 1872, II, pp. 197-227.

54 Scarborough, ibid.; CIL XIII 5208. Other misprints or errors in n. 27 are these: CIL XIII 7943 (M. Sabinianus Quietus) is a miles medicus of a vexillation of leg.I.Minervia, stationed at Iversheim; CIL III 14347.5; III 5959 comes from Castra Regina, as does 6532, which can not be used as an example of a medicus ordinarius.; III 3413 reads Marcius Marcellus; 14349 shows that C. Numidius Optervius had completed thirteen stipendia, years of service. More details of the doctors and other medical inhabitants of the legionary fortress of Aquincum can be found in G. Korbuly, 'Aquincum Orvosi Emlékei', Dissertationes Pannonicae, I.3, Budapest, 1934.

${ }_{55}$ Scarborough, pp. 258-59.

so R. Egger, 'Das Praetorium als Amtssitz und Quartier römischer Spitzenfunktionäre', Sber. Akad. Wiss. Wien, 1966, 250.4, 33ff., 42.

${ }_{57}$ Scarborough, p. 258 n. 27; For Greek doctors in the army, see Dessau's note on ILS 2542 , Callies, 19, 21.

${ }_{58}$ W. Dittenberger, Orientis Graeci Inscriptiones Selectae, Leipzig, 1903-5, p. 207; the reading of the last part of the stone is very uncertain. 


\section{Vivian Nutton}

to suggest that he was a temple physician or even an Egyptian, and his obviously Latin name could be used to deny this.

These comments upon Scarborough's interpretation of the evidence contained in one paragraph only of his article may suggest the unreliability of much of his interpretation elsewhere. In an attempt to reduce the medical services of the Roman army to an 'unofficial' and 'informal organization', even though he is reduced to using 'system' and 'pattern' to explain similarities without considering the possibility of a 'formal organization', he neglects much of the evidence assembled by Haberling, Gummerus and Casarini, and by concentrating upon the literary evidence of different ages, which depicts Roman military medicine in isolation, he produces a lop-sided and confused account. ${ }^{59}$ Although his comments upon republican medicine have value and are a salutary corrective to some ill-conceived speculation, his failure to notice the changes in the Roman army or to place the doctors within a military context, as was done by Domaszewski, and more recently by Callies, vitiates most of his comments upon the Roman imperial army. ${ }^{60}$

It would be wrong to end with these captious criticisms and to refrain from putting forward any suggestions for future work. Some idea will have been gained of my approach, and the way in which I hope to resolve some of the difficulties of the inadequate sources. One must consider the doctors in two ways. First in relation to Roman society and Roman medicine, one must examine their methods of entry into the army, their training, their education, and their prospects. Secondly the doctor must be placed in the context of the army. There is no satisfactory work on the specialists in the army, the architecti, the mensores, the clerical staff, the doctors, their position, recruitment and qualifications, and the problem of the medicus ordinarius can only be solved by a consideration of all these groups. Even though the doctor is supposed, especially by sociologists, to be above all the specialist whose services are necessary and yet ideologically incompatible with the aims of the army, which makes a study of his position so interesting, it is unwise to view him in isolation. ${ }^{61}$ Modern works on the Roman army must be used, and the archaeological evidence for the existence of doctors and legionary hospitals can be brought to reveal more than Schultze thought. Epigraphic surveys, such as that of Gummerus, go some way to answering many of the problems, yet by their very nature they deal with fragmentary and isolated pieces of evidence that can only with difficulty be placed in a general context, and problems are seen in relation to individual inscriptions rather than to the Roman army or to Roman medicine as a whole.

The amount of evidence is not large, the problems are numerous, yet by a diligent and careful examination of all the pieces, considered in context and with a clear definition of terms, it is possible to reach a sure conclusion, even if much is to be left unresolved in doubt.

\footnotetext{
50 W. Haberling, 'Die altrömischen Militärärzte', Veröffe. Geb. Milit. Sanitätsw., 1910, 42, was the first to publish a corpus of inscriptions relating to military medicine.

so A recent work on the republican army, A. Harmand, L'armée et le soldat à Rome, 107-50, Paris, 1967, pp. $202 \mathrm{ff}$., attempts to supplement the meagre literary accounts of the medical service of Caesar's army by a comparison with the French army of the sixteenth century and to draw conclusions from this comparison. His methods have been roundly condemned by $M$. Rambaud, 'Légion et armée romaines', Revue des Études Latines, 1967, 45, 112-47 (145-46).

s1 Cf. C. H. Coates and R. J. Pellegrin, Military Sociology, Maryland University Press, 1965, $238-41$.
} 